\title{
Electrophotocatalytic $S_{N} A r$ Reactions of Unactivated Aryl Fluorides at Ambient Temperature and Without Base.
}

\author{
He Huang ${ }^{[a]}$, Tristan H. Lambert ${ }^{[a]}$ \\ [a]Department of Chemistry and Chemical Biology, Cornell University, Ithaca, NY 14853, USA
}

\begin{abstract}
The electrophotocatalytic $\mathrm{S}_{\mathrm{N}} \mathrm{Ar}$ reaction of unactivated aryl fluorides at ambient temperature without strong base is demonstrated.
\end{abstract}

\section{Graphical Abstract}

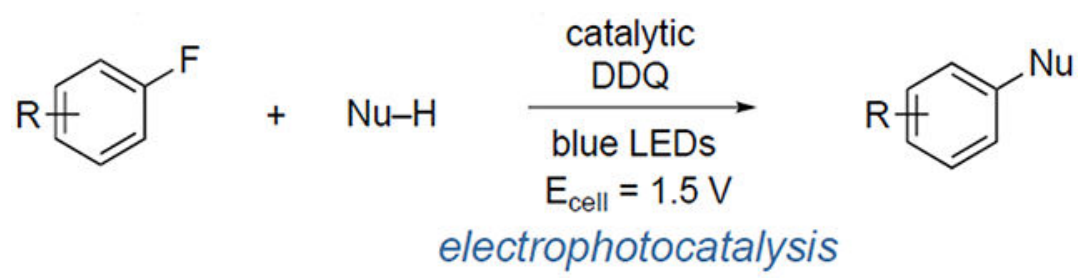

Unactivated aryl fluorides engage in $\mathrm{S}_{\mathrm{N}} \mathrm{Ar}$ reactions at room temperature and without the strong base using DDQ as an electrophotocatalyst.

\section{Keywords}

Electrophotocatalysis; $\mathrm{S}_{\mathrm{N}} \mathrm{Ar}$; arylation; electrochemistry; photochemistry

Nucleophilic aromatic substitution $\left(\mathrm{S}_{\mathrm{N}} \mathrm{Ar}\right)$ reactions have long been an important strategic tool for organic synthesis, enabling the direct arylation of nucleophilic substrates. ${ }^{[1,2]}$ Classically, $\mathrm{S}_{\mathrm{N}} \mathrm{Ar}$ reactions operate on activated arenes $\mathbf{3}$ bearing strongly electronwithdrawing functionality (EWG, Figure 1A). ${ }^{[3-8]}$ While such reactions have great utility, such substituents are often not synthetically desirable and thus represent a significant limitation for this reaction class. On the other hand, several reports have described $S_{N} A r$ reactions with unactivated substrates $\mathbf{4}$ through the use of strong bases and high reaction temperatures. ${ }^{[9-13]}$ Unfortunately, many complex substrates are not compatible with such conditions, which thus precludes the broad adoption of these methods. As such, the development of $\mathrm{S}_{\mathrm{N}} \mathrm{Ar}$ reactions that occur on unactivated substrates at ambient temperature without the need for strongly basic reagents has presented a significant challenge.

In this regard, a new entry in the $S_{N} A r$ arena was recently reported by Nicewicz, who found that alkoxy arenes could undergo nucleophilic substitution via photoredox catalysis (Figure 
1B). ${ }^{[14]}$ Mechanistically, these reactions were thought to be initiated by single-electron photooxidation of the alkoxyarene 5 to generate a radical cation $\mathbf{6}$. Subsequent nucleophilic attack, reduction of the resulting radical intermediate 7 (nominally by the reduced acridinium photocatalyst, Acr•), and rearomatization with expulsion of the alkoxy substituent then furnished the substitution products $\mathbf{2}$. This method represented a notable new strategy for $\mathrm{S}_{\mathrm{N}} \mathrm{Ar}$ reactions and expanded the scope of nucleofugal groups to include alkoxy substituents. On the other hand, this substrate expansion also represented a limitation, in that the electron-donating alkoxy substituents were necessary to achieve the initial oxidation event. It therefore remains a challenge to develop $\mathrm{S}_{\mathrm{N}} \mathrm{Ar}$ methods of the Nicewicz type that accommodate unactivated aromatics and a broader range of nucleofugal groups. However, overcoming this challenge requires the identification of a catalyst oxidizing enough to achieve the initial single-electron oxidation of less electron-rich substrates while retaining the ability to reduce the intermediate radical complex (cf. 7). ${ }^{[15-17]}$ In this Communication, we report that an electrophotocatalytic ${ }^{[18]}$ strategy solves this problem and enables $S_{N} A r$ reactions of unactivated aryl fluorides at room temperature and without strong base.

We recently described the oxidative coupling reactions of strongly deactivated arenes, such as 1,4-dichlorobenzene (8), using a trisaminocyclopropenium (TAC) ion electrophotocatalyst (Figure 1C). ${ }^{[19]}$ Unexpectedly, when we attempted the reaction of 1-chloro-4-fluorobenzene 11 under the same conditions, the major product observed was not that of $\mathrm{C}-\mathrm{H} / \mathrm{N}-\mathrm{H}$ coupling, but rather ipso substitution of the fluoride (Figure 1D). For the reasons discussed above, this transformation was notable in that it occurred at room temperature under mildly acidic conditions $(\mathrm{AcOH})$ and on a (classically) unactivated substrate. Here, we report on the further development of this electrophotocatalytic $S_{N} A r$ method.

In terms of optimization (Table 1), the original reaction was performed in the presence of 8 mol\% TAC 13 in an undivided cell $\left(\mathrm{E}_{\text {cell }}=1.5 \mathrm{~V}\right)$ under irradiation by white light with $\mathrm{LiClO}_{4}$ and $\mathrm{AcOH}$ in acetonitrile (Table 1, entry 1). Despite extensive screening, we were unable to achieve higher yields with catalyst 13. Alternatively, 2,3-dichloro-5,6-

dicyanoquinone (DDQ, 14), which has a similar excited state reduction potential ${ }^{[20-26]}$, has also been used for arene photooxidations. ${ }^{[22]}$ Using $10 \mathrm{~mol} \%$ DDQ and blue light-emitting diodes (LEDs) but otherwise identical conditions, the product 12 was generated in 60\% yield. The use of less $\mathrm{LiClO}_{4}$ was detrimental (entry 3), but other electrolytes were more effective (entries 4 and 5), with one equivalent of tetrabutylammonium tetrafluoroborate $\left(\mathrm{TBABF}_{4}\right)$ showing the highest efficiency (entry 5). Blue LEDs were optimal, with a compact fluorescent light (CFL) resulting in a greatly diminished yield (entry 6). No conversion was observed in the dark (entry 7). Interestingly, without current (but with irradiation), there was no catalyst turnover (entry 8), and the same reaction without acid and electrolyte produced similar results (entry 9). As expected, without catalyst no reaction occurred (entry 10). Meanwhile, 1.0 and $2.0 \mathrm{~V}$ both led to catalytic turnover (entries 11 and 12), but the yield using $1.5 \mathrm{~V}$ was superior. Finally, we found that the use of $20 \mathrm{~mol} \%$ catalyst furnished a higher yield (entry 13), and $15 \mathrm{~mol} \%$ DDQ added in two portions was equally effective (entry 14). 
We next examined the scope of this reaction (Table 2). Using 4-fluorochlorobenzene (11), pyrazoles bearing carbonyl functionality furnished products 12-16 in good yield (entries 1-3), while halogenated pyrazoles also participated efficiently (entries 4-6). 1,2,3-triazoles were productive as well, leading to adducts $\mathbf{2 0}$ and $\mathbf{2 1}$ (entries 7 and 8). The reaction of 6bromobenzotriazole led to $\mathbf{2 2}$ in good yield and with a 1:1 regioselectivity for arylation of the two nitrogens. Both 1,3,5-triazoles (entries 10 and 11) and tetrazole (entry 12) could be arylated as well, although yields were modest in these cases.

In terms of the fluoroarene component, we found 1,4-difluorobenzene to be particularly effective as an arylating reactant, giving rise to adduct $\mathbf{2 6}$ in 90\% yield (entry 13). Interestingly, it also proved possible to utilize 1,4-difluoro-2-methylbenzene to generate the product 27 (entry 14), in which the 1-fluoro group was substituted selectively. We speculate that the adjacent methyl group might support greater cationic character at the 1-position of the intermediate radical cation, leading to this surprising selectivity. The use of 1-bromo-4fluorobenzene led to product 28 (entry 15), while, 4-tert-butyl-1-fluorobenzene was also productive to form $\mathbf{2 9}$ (entry 16). Additionally, the use of 1,2-difluorobenzenes led to products 30 and $\mathbf{3 1}$ (entries 17 and 18) in modest yields. On the other hand, 1,3difluorobenzene was not an effective participant in this method (entry 19). Remarkably, however, fluorobenzene gave rise to the phenylated adduct 33 in $45 \%$ yield (entry 14), albeit with the production of a significant amount of $\mathrm{C}-\mathrm{H} / \mathrm{N}-\mathrm{H}$ coupled product as well.

Fluoroarenes bearing strongly electron-withdrawing groups did not lead to arylated products (e.g. entry 21).

To illustrate the applicability of this method to the synthesis of more complex molecules, we also synthesized the products shown in entries 22-28. Thus, a variety of halogenated purines (entries 22-25), a steroidal ester-fused pyrazole (entry 26), and -aminoester-fused pyrazoles (entries 27 and 28) could be N-arylated. Notably, the ester moieties of adducts 40-42 are representative of functional groups that could be labile under the strongly basic conditions of classic $\mathrm{S}_{\mathrm{N}} \mathrm{Ar}$ reactions, but which are compatible with the current method.

Other nucleophiles can also participate (Table 3). For example, simple alcohols reacted with 1,4-difluorobenzene to furnish aryl ethers $\mathbf{4 3}$ and $\mathbf{4 4}$ in good yields (entries 1 and 2). Cyclopropyl- and cyclopentylmethanol were also viable nucleophiles (entries 3 and 4), as was menthol (entry 5). The more functionalized 4-pentyn-1-ol led to $\mathbf{4 8}$ in serviceable yield ethanol to furnish ether $\mathbf{5 0}$ (entry 8), while 4-tert-butyl-1-fluorobenzene and methanol led to 51 in 50\% yield (entry 9). Interestingly, we found that water was also capable of serving as a nucleophile (entry 10), although the yield of 4-fluorophenol (52) was low. In terms of nitrogen nucleophiles, $O$-tert-butylcarbamate led to the formation of $N$-Boc-4-fluoroaniline (53) (entry 6), and a protected sugar could be engaged despite concerns of oxidative destruction of the acetal moiety (entry 7). Meanwhile, reaction of some alternative aryl fluorides was also productive. For example, 1-chloro-4-fluorobenzene reacted with in 35\% yield (entry 11). We found that an unprotected amine like $i$-propylamine was not viable, however (entry 12).

A mechanistic rationale for this chemistry is shown in Figure 2. Photoexcitation of DDQ (14) produces an excited state species $\mathbf{5 5}$ which is potent enough $\left(\mathrm{E}_{\text {red }}=3.18 \mathrm{~V} \text { vs SCE }\right)^{[21]}$ 
to oxidize fluoroarene 11. Nucleophilic attack by pyrazole 9 to the resulting radical cation $\mathbf{5 7}$ then produces radical $\mathbf{5 8}$. We presume that $\mathbf{5 8}$ must undergo a one-electron reduction to furnish anion $\mathbf{5 9}$ in order to expel the fluoride leaving group to form product 21. However, because DDQ radical anion $\mathbf{5 6}$ is a poor reductant, ${ }^{[15-21,27]}$ the catalytic cycle likely cannot be closed by transfer of an electron from $\mathbf{5 6}$ to $\mathbf{5 8}$, but rather the reduction of $\mathbf{5 8}$ and the reoxidation of $\mathbf{5 6}$ must be accomplished by the electrotrodes. Additional support for this mechanistic rationale is provided in the supporting information.

For the reactions shown in Table 3, the products have lower oxidation potentials than the starting materials, and so it is perhaps remarkable that the products remain intact. Indeed, we have found that alkoxybenzenes do not undergo any reaction (Scheme S1 in SI), either with pyrazoles or alcohols as might be expected from the mechanistic proposal and the precedent of Nicewicz. We propose that, although the single-electron oxidation event is facile, the back-electron transfer is very rapid and thus outcompetes nucleophilic attack to the transient radical cation intermediate. Indeed, a similar rationale has been advanced in the DDQ photoxidation of benzene to phenol. ${ }^{[21]}$

The ability to achieve $S_{N} A r$ reactions on unactivated substrates under mild conditions offers unique possibilities for chemoselective reactions (Scheme 1). For example, we subjected pyrazole 9 and a 1:1 mixture 1-chloro-4-fluorobenzene (11) and 1-fluoro-2,4-dinitrobenzene (60) to our standard reaction conditions, under which adduct $\mathbf{1 2}$ was formed in $65 \%$ yield as the only observable product. Aryl fluoride $\mathbf{6 0}$ was left untouched by these conditions. Meanwhile, 1-chloro-4-fluorobenzene (11) was also selectively converted to $\mathbf{1 2}$ in the presence of 4-fluoroanisole (43), with the latter left intact.

In conclusion, we have developed an electrophotocatalytic method for $\mathrm{S}_{\mathrm{N}} \mathrm{Ar}$ reactions of unactivated fluorides that occurs at room temperature and without the use of strong base. This method offers an arylation technology complementary to existing $\mathrm{S}_{\mathrm{N}} \mathrm{Ar}$ methods. Furthermore, this work advances the nascent area of electrophotocatalysis by demonstrating how the combination of light and electrical energy can be used to promote redox neutral reactions.

\section{Supplementary Material}

Refer to Web version on PubMed Central for supplementary material.

\section{Acknowledgements}

Research reported in this publication was supported by the National Institutes of Health under R35 GM127135.

\section{References}

[1]. Amii H, Uneyama K, Chem. Rev 2009, 109, 2119-2183. [PubMed: 19331346]

[2]. Smith M, March J, March's Advanced Organic Chemistry: Reactions, Mechanisms, and Structure, Wiley-Interscience, Hoboken, 2007, pp. 853-933.

[3]. Jitchati R, Batsanov AS, Bryce MR,Tetrahedron 2009, 65, 855-861.

[4]. Huang A, Liu F, Zhan C, Liu Y, Ma C, Org. Biomol. Chem 2011, 9, 7351-7357. [PubMed: 21894335]

Angew Chem Int Ed Engl. Author manuscript; available in PMC 2021 January 07. 
[5]. Bella M, Kobbelgaard S, Jorgensen KA, J. Am. Chem. Soc 2005, 127, 3670-3671. [PubMed: 15771481]

[6]. Lautrette G, Touti F, Lee HG, Dai P, Pentelute BL, J. Am. Chem. Soc 2016, 138, 8340-8343. [PubMed: 27332147]

[7]. Wang X, Tang Y, Long CY, Dong WK, Li CC, Xu XH, Zhao WX, Wang XQ, Org. Lett 2018, 20, 4749-4753. [PubMed: 30052455]

[8]. Travieso-Puente R, Budzak S, Chen J, Stacko P, Jastrzebski JTBH, Jacquemin D, Otten E, J. Am. Chem. Soc 2017, 139, 3328-3331 [PubMed: 28218846]

[9]. Diness F, Fairlie DP, Angew. Chem. Int. Ed 2012, 51, 8012-8016;Angew. Chem 2012, 124, 81368140 .

[10]. Zheng Y, Batsanov AS, Jankus V, Dias FB, Bryce MR, Monkman AP, J. Org. Chem 2011, 76, 8300-8310. [PubMed: 21950840]

[11]. Borch Jacobsen C, Meldal M, Diness F, Chem. Eur. J 2017, 23, 846-851. [PubMed: 27739610]

[12]. Lin YY, Li M, Ji XF, Wu JJ, Cao S, Tetrahedron 2017, 73, 1466-1472.

[13]. Mao J, Wang Z, Xu X, Liu G, Jiang R, Guan H, Zheng Z, Walsh PJ, Angew. Chem. Int. Ed 2019, 58, 11033-11038;Angew. Chem 2019, 131, 11149-11154.

[14]. Tay NES, Nicewicz DA, J. Am. Chem. Soc 2017, 139, 16100-16104. [PubMed: 29068677]

[15]. Romero NA, Nicewicz DA, Chem. Rev 2016, 116, 10075-10166. [PubMed: 27285582]

[16]. Fukuzumi S, Ohkubo K, Org. Biomol. Chem 2014, 12, 6059-6071. [PubMed: 24984977]

[17]. Prier CK, Rankic DA, MacMillan DWC, Chem. Rev 2013, 113, 5322-5363. [PubMed: 23509883]

[18]. For examples of electrophotocatalysis or photoelectrocatalysis, see:(a) Moutet J-C, Reverdy G, J. Chem. Soc., Chem. Commun 1982, 654-655.(b) Scheffold R, Orlinski R, J. Am. Chem. Soc 1983, 105, 7200-7202.(c) Yan H, Hou Z-W, Xu H-C, Angew. Chem. Int. Ed 2019, 58, 4592 4595;Angew. Chem 2019, 131, 4640-4643.See also:(d) Wang F, Stahl SS, Angew. Chem. Int. Ed 2019, 58, 6385-6390; Angew. Chem 2019, 131, 6451-6456.

[19]. Huang H, Strater ZM, Rauch M, Shee J, Sisto T, Nuckolls C, Lambert TH, Angew. Chem. Int. Ed 2019, 58, 13318-13322;Angew. Chem 2019, 131, 13452-13456.

[20]. Wendlandt AE, Stahl SS, Angew. Chem. Int. Ed 2015, 54, 14638-14658;Angew. Chem 2015, 127, 14848-14868.

[21]. Walker D, Hiebert JD, Chem. Rev 1967, 67, 153-195. [PubMed: 4859921]

[22]. Ohkubo K, Fujimoto A, Fukuzumi S, J. Am. Chem. Soc 2013, 135, 5368-5371. [PubMed: 23534829]

[23]. Das S, Natarajan P, Konig B, Chem. Eur. J 2017, 23, 18161-18165. [PubMed: 29143992]

[24]. Song C, Yi H, Dou B, Li Y, Singh AK, Lei A, Chem. Commun 2017, 53, 3689-3692.

[25]. Ohkubo K, Hirose K, Fukuzumi S, Chem. Asian. J 2016, 11, 2255-2259. [PubMed: 27399906]

[26]. Rusch F, Schober J-C, Brasholz M, Chem. Cat. Chem 2016, 8, 2881-2884.

[27]. Huynh MT, Anson CW, Cavell AC, Stahl SS, Hammes-Schiffer S, J. Am. Chem. Soc 2016, 138, 15903-15910. [PubMed: 27960306] 
A. $S_{N} A r$ with aryl halides

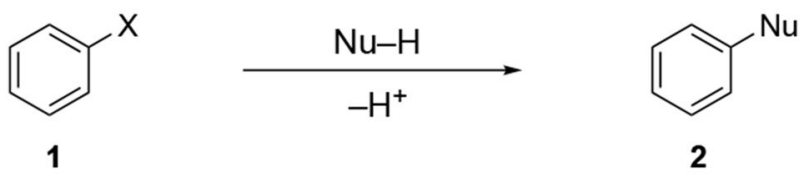<smiles>[X]c1ccc(OCC)cc1</smiles>

3 activated requires EWG, strong base<smiles>[R]c1ccc(F)cc1</smiles>

4

unactivated (previous) requires high temp, strong base<smiles>[R]c1ccc(F)cc1</smiles>

unactivated (this work)

electrophotocatalytic $\rightarrow$ room temp, no strong base

B. Photoredox-catalyzed $S_{N} A r$ of alkoxyarenes (Nicewicz 2017)

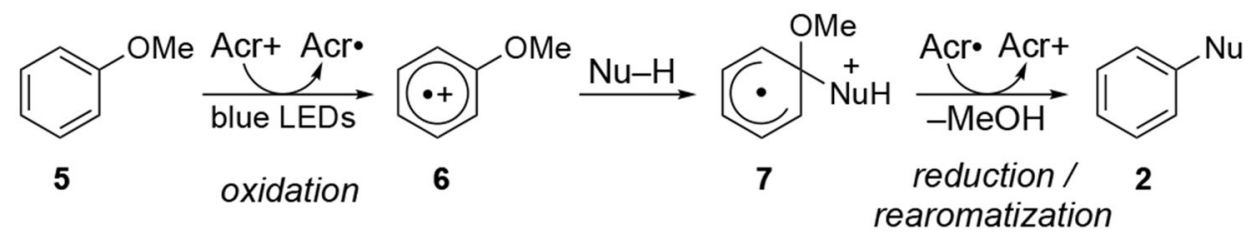

C. Electrophotocatalytic $\mathrm{C}-\mathrm{H} / \mathrm{N}-\mathrm{H}$ coupling (previous work)

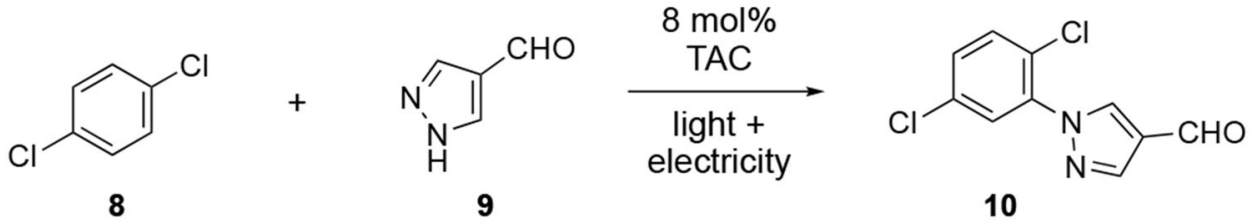

D. Electrophotocatalytic $S_{N} A r$ of unactivated aryl fluorides (this work)<smiles>O=Cc1cn[nH]c1</smiles>

11<smiles>O=Cc1cnn(-c2ccc(Cl)cc2)c1</smiles>

12

Figure 1.

$\mathrm{S}_{\mathrm{N}} \mathrm{Ar}$ reactions, including classic, photoredox-catalyzed, and electrophotocatalytic variants. 


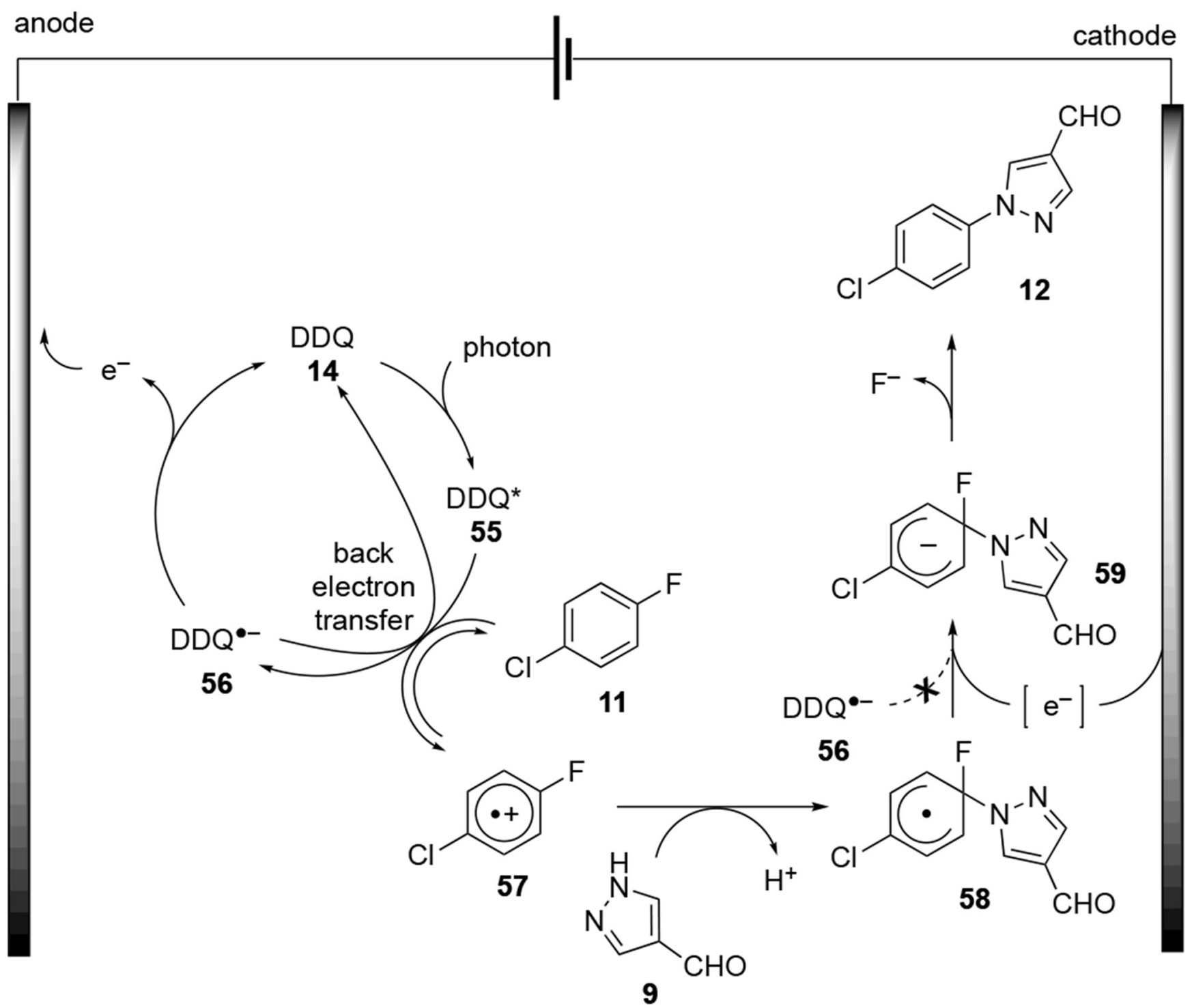

Figure 2.

Proposed mechanism for electrophotocatalytic $S_{N} A r$ reaction. 


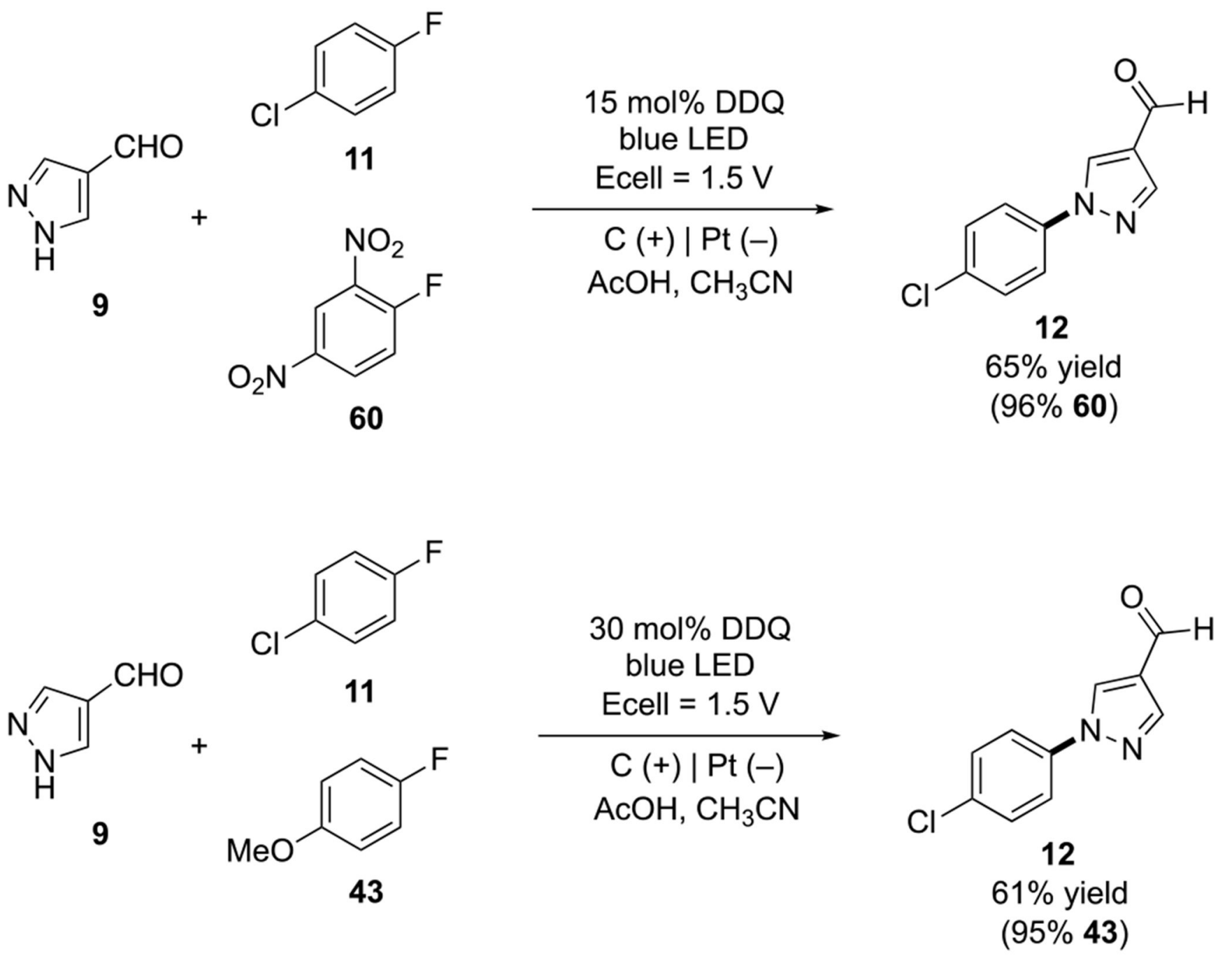

Scheme 1.

Demonstration of chemoselectivity. 
Table 1.

Catalyst optimization studies. ${ }^{[a]}$

\begin{tabular}{|c|c|c|c|c|c|}
\hline & 11 & 9 & $\begin{array}{c}\text { electrophotocatalyst } \\
\text { constant voltage } \\
\mathrm{AcOH} \text {, electrolyte } \\
\mathrm{C}(+) \mid \mathrm{Pt}(-) \\
\text { blue } \mathrm{LED} \\
\mathrm{CH}_{3} \mathrm{CN}\end{array}$ & $\overbrace{}^{N}$ & $\mathrm{CHO}$ \\
\hline entry & catalyst (mol\%) & $\mathbf{E}_{\text {cell }}(\mathbf{V})$ & electrolyte (equiv.) & other & yield $(\%)^{b}$ \\
\hline $1^{c}$ & $13(8)$ & 1.5 & $\mathrm{LiClO}_{4}(6)$ & CFL & 25 \\
\hline 2 & $14(10)$ & 1.5 & $\mathrm{LiClO}_{4}(6)$ & - & 60 \\
\hline 3 & $14(10)$ & 1.5 & $\mathrm{LiClO}_{4}(1)$ & - & 23 \\
\hline 4 & $14(10)$ & 1.5 & $\operatorname{TBAPF}_{6}(1)$ & - & 45 \\
\hline 5 & $14(10)$ & 1.5 & $\mathrm{TBABF}_{4}(1)$ & - & 60 \\
\hline 6 & $14(10)$ & 1.5 & $\mathrm{TBABF}_{4}(1)$ & CFL & 18 \\
\hline 7 & $14(10)$ & 1.5 & $\mathrm{TBABF}_{4}(1)$ & no light & 0 \\
\hline 8 & $14(10)$ & - & $\mathrm{TBABF}_{4}(1)$ & no current & 12 \\
\hline 9 & $14(10)$ & - & - & no current, no acid & 11 \\
\hline 10 & - & 1.5 & $\mathrm{TBABF}_{4}(1)$ & no catalyst & 0 \\
\hline 11 & $14(10)$ & 1.0 & $\mathrm{TBABF}_{4}(1)$ & - & 32 \\
\hline 12 & $14(10)$ & 2.0 & $\mathrm{TBABF}_{4}(1)$ & - & 50 \\
\hline 13 & $14(20)$ & 1.5 & $\mathrm{TBABF}_{4}(1)$ & - & 75 \\
\hline 14 & $14(15)^{d}$ & 1.5 & $\mathrm{TBABF}_{4}(1)$ & & $75(73)^{e}$ \\
\hline & $E_{\text {red(radical dication) }}$ & $3.33 \mathrm{Vv}$ & SCE & $\begin{array}{c}\text { DDQ (14) } \\
\text { excited) }=3.18 \mathrm{~V} \text { vs }\end{array}$ & \\
\hline
\end{tabular}

${ }^{[a]}$ Reaction conditions: 11 (2.0 mmol, 5.0 equiv), 9 ( $0.4 \mathrm{mmol}, 1.0$ equiv), electrophotocatalyst ( $0.04 \mathrm{mmol}, 0.1$ equiv), $\mathrm{MeCN}(6.0 \mathrm{~mL}), \mathrm{AcOH}$ ( $4.0 \mathrm{mmol}, 10$ equiv), TBABF 4 ( $0.4 \mathrm{mmol}, 1.0$ equiv), $\mathrm{N}_{2}$, carbon felt anode, Pt cathode. Reactions performed under constant voltage conditions with irradiation for $24 \mathrm{~h}$ at rt.

${ }^{[b]}$ Yields determined by ${ }^{1}$ H NMR.

$[c] 2.0 \mathrm{ml} 11$ was used.

[d] $15 \%$ catalyst added in two portions, $36 \mathrm{~h}$ reaction time.

${ }^{[e]}$ Yield of isolated product. 


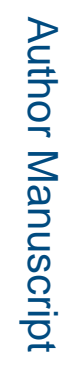

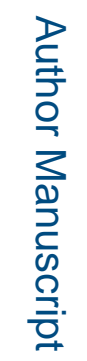

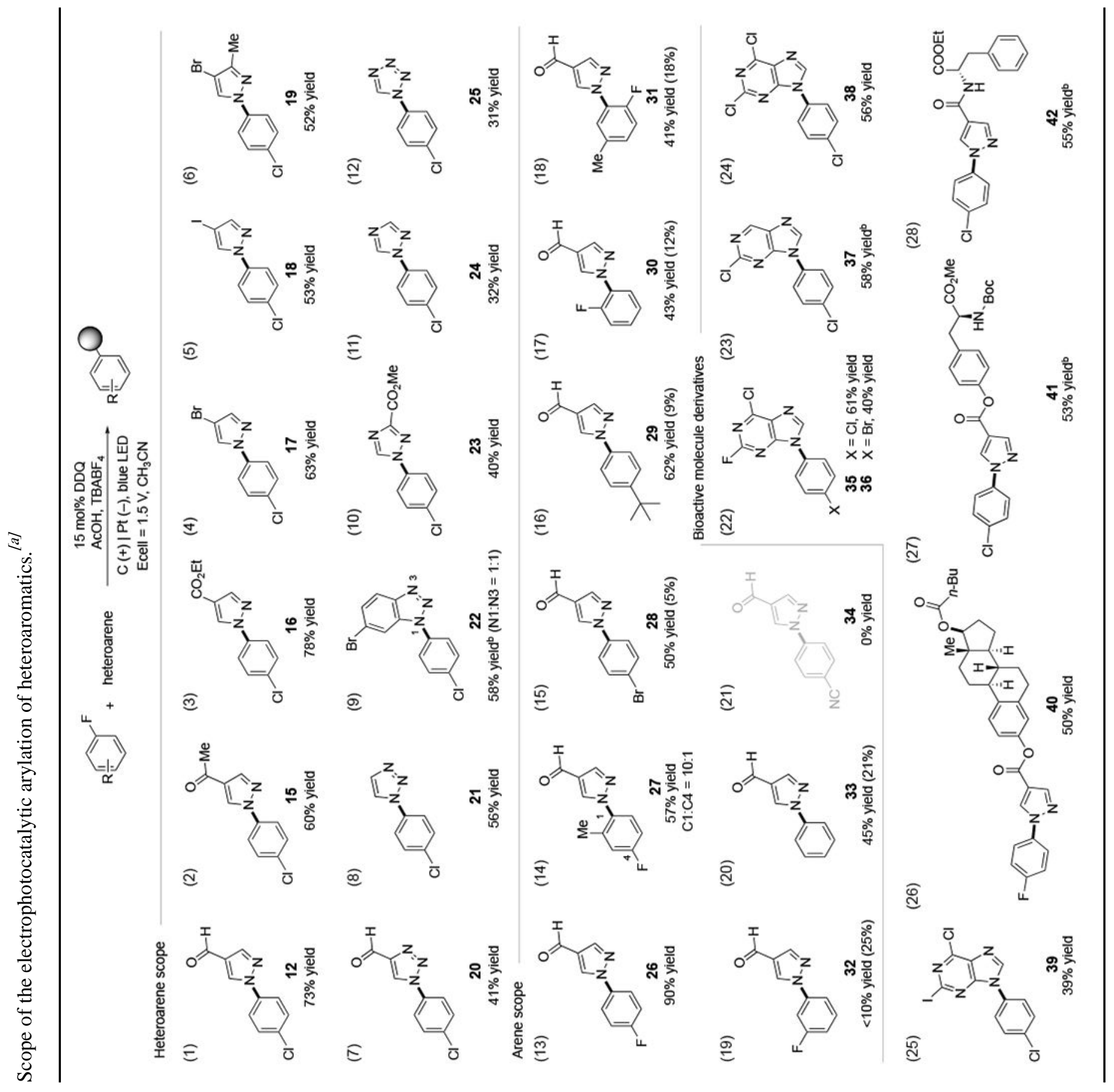

Angew Chem Int Ed Engl. Author manuscript; available in PMC 2021 January 07. 


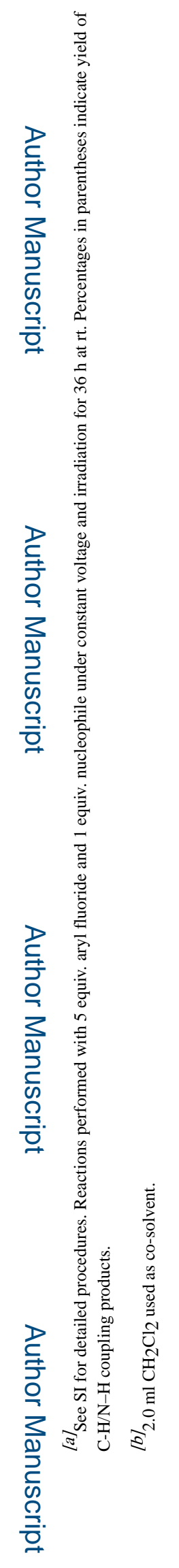


Table 3.

Electrophotocatalytic $\mathrm{S}_{\mathrm{N}} \mathrm{Ar}$ reactions with various nucleophiles. ${ }^{[a]}$

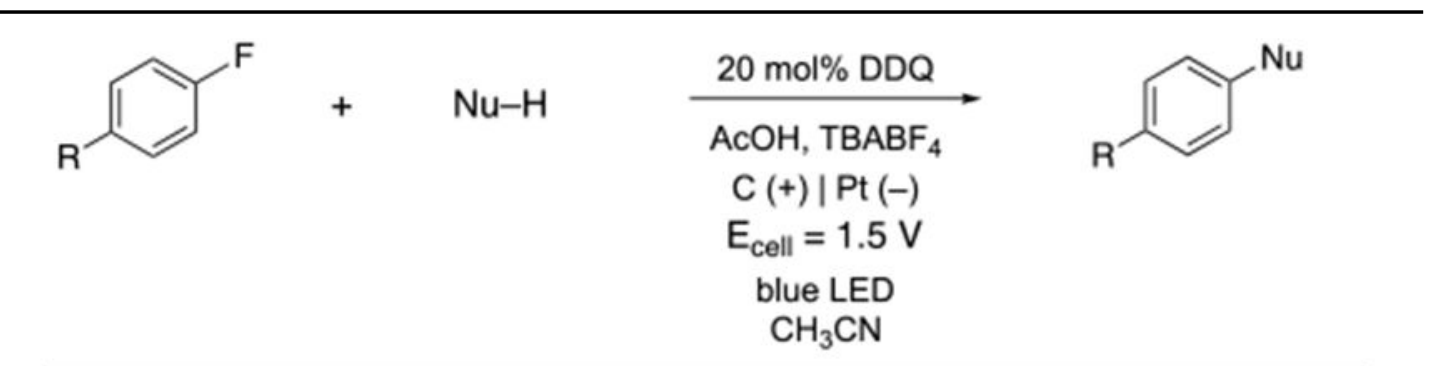

로을

(1)<smiles>COc1ccc(F)cc1</smiles>

(4)<smiles>Fc1ccc(OCC2CCCC2)cc1</smiles>

(7)

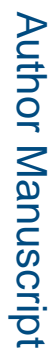

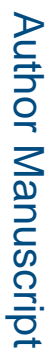

43

$63 \%$ yield $^{b}$

(2)<smiles>CCOc1ccc(F)cc1</smiles>

44

$65 \%$ yield $^{\mathrm{b}}$

(5)

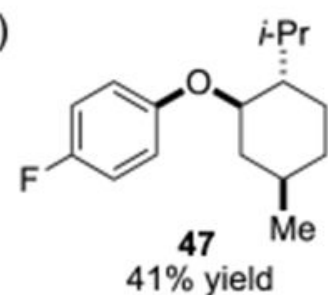

(8)<smiles>CCOc1ccc(Cl)cc1</smiles>

50

$52 \%$ yield $^{c}$

(11)<smiles>Oc1ccc(F)cc1</smiles>

52

$28 \%$ yield $^{b}$

53

$35 \%$ yield
(3)<smiles>Fc1ccc(OCC2CC2)cc1</smiles>

45

$43 \%$ yield

(6)<smiles>C#CCCCOc1ccc(F)cc1</smiles>

48

$53 \%$ yield

(9)<smiles>COc1ccc(C(C)(C)C)cc1</smiles>

51

$50 \%$ yield $^{c}$

(12)<smiles>CC(C)(C)OC(=O)Nc1ccc(F)cc1</smiles>

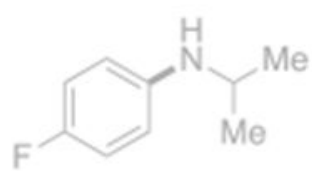

54 no reaction

\footnotetext{
${ }^{[a]}$ Reactions performed with 5 equiv. aryl fluoride and 1 equiv. nucleophile under constant voltage and irradiation at $\mathrm{rt}$ for $24-36 \mathrm{~h}$.

${ }^{[b]}$ Yield determined by UPLC.
} 


\section{${ }^{[c]}$ Yield determined by ${ }^{1} \mathrm{H}$ NMR.}

